\title{
3
}

\section{REFLECTING ON EXPERIMENTAL MUSEOLOGY AT THE MUSEUM OF MEMORY OF COLOMBIA}

\author{
Jennifer Carter and Cristina Lleras
}

And we need these histories to affirm their plurality, because it is not a matter of constructing a model but of a practical experiment.

Isabelle Stengers, In catastrophic times (2009/2015), p. 132

Our chapter invokes the concept of experimental museology in its most fundamental terms, namely as the ground of analysing how the staff and planning team of a national museum-in-the-making - as yet unconstrained by the realities of the everyday functioning of a bricks-and-mortar building - imagined a memorial museum's coming-into-being by experimenting with the very idea of the 'why' and 'how' of a museum (and in which the former - the why - directly affects the latter - the how). Seeking to create a public space in which to present a multidimensional account of Colombia's long-standing armed conflict - one that would escape the logic of a victim-perpetrator binary and involve visitors in an introspective and self-reflexive engagement toward a peaceful future - the team adopted an innovative approach to curation and design and tested this approach in the temporary exhibition it curated and produced, Voces para transformar a Colombia (Voices for the Transformation of Colombia, herein, Voces). It formed part of the visioning exercise inherent in the planning of the Museum of Memory in the Colombian capital, Bogotá.

In this chapter, we consider not only the how, why and to what ends of this ephemeral experiment within the context of an institution in which notions of conservation and permanence have historically constituted its key aims, we also ask what happens when process becomes praxis, as it did throughout the conception phase of the Museum of Memory. Our conviction is that by embracing concepts that have hitherto been considered antithetical to the museum's wellbeing as a risk-adverse environment throughout the processes of curation and design, the museum team's timely reconsideration of the conceptual foundations and 
framework of museums may ultimately be of benefit to future thinking and praxis within the field.

The Museum of Memory is mandated by Law 1448, the 2011 Victims and Land Restitution Law, crafted as part of transitional justice measures taken by the Colombian government to address the history of the country's prolonged armed conflict and its violations that spanned the second half of the twentieth century. As such, the museum intends to be both a memorial museum and a museum of human rights. Colombia's near 60-year internal conflict has profoundly scarred the landscape and the Colombian people, irrespective of gender, age and political affiliation. Members of the government, the military, paramilitary and guerrillas have all played roles in this conflict as has a broader network of social actors who have gained profit by virtue of the conflict's shifting dynamics of power over time. The complexities of the conflict run deep, and its traumatic legacies on the country's psyche even deeper. While it is difficult to know for certain the number of those affected by such a lengthy armed conflict, some have estimated it has claimed as many as nine million victims through the diverse forms of violence that have been perpetrated, including displacement, homicide, massacres, kidnappings and disappearances (Unidadvictimas, n.d.).

Within the context of an evolving peace process initiated post-2005 (International Center of Transitional Justice, 2020) and in an attempt to overcome the profound social and political differences that have divided the country for many decades, Juan Manuel Santos's government foresaw a new national museum as a means to engage Colombians in 'social reconciliation' and 'symbolic repair.' These concepts - like many others derived from the transitional justice field - are abstract and signify different things to different people (Global Initiative for Justice, Truth and Reconciliation, 2017, p. 12), and the roles and possibilities of museums at large in transitional justice contexts are the subject of ongoing exploration and debate owing to the distinct political contexts in which these institutions have, or are, emerging (for example in Chile, Colombia, Paraguay, Taiwan and Canada). Yet, their importance in the development of this new national museum lies in the space of exchange that their invocation has opened up, allowing for Colombians to envision both a way of sharing and processing their diverse perspectives and experiences of the country's traumatic past and a collective formation of a way forward.

This chapter addresses the visioning process of the Museum of Memory through a description and theorisation of the planning, creation and inauguration of Voces. As a first temporary, off-site exhibition of the museum, it served as a platform of experimentation for the small museum team engaged in its development. We begin with a brief discussion of the research methodology used in our analysis of Voces and the presentation of a theoretical framework which contextualises the Museum of Memory and Voces in relation to the evolving genres of memorial museums (since the late 1940s) and human rights museums (since the mid-1980s) and the range of roles and responsibilities mandated to these museums. We then analyse how the concepts of narrative, metaphor and spatial trajectories - 
informed by strategies of design thinking, in which parts are understood in intimate connection and interconnection with the whole - became the grounds for experimenting with modes of engagement with traumatic pasts and presents. The goal of the exhibition was to effect profound change in individual and collective behaviour by encouraging Colombians to question their own understanding and personal narrative of the armed conflict and their position within this narrative.

\section{In search of a new way of doing: methods and approach}

Those who have lived through armed conflict and those who have studied it will recognise a now familiar trope within memorial museums' narrations of war: a deliberate recounting of the horrors of conflict punctuated by stories of solidarity, resistance, peace efforts and hope (Centro Nacional de Memoria Histórica, 2018; Thiemeyer, 2019). This museographical acknowledgement was one of the working premises of the research and historical memory initiatives carried out by the National Center for Historical Memory, ${ }^{1}$ a public institution tasked with contributing to 'the comprehensive reparation and to the right to the truth for the victims of the Colombian armed conflict as well as society in general,' and which oversaw the creation of the Museum of Memory as one manifestation of this mandate (United Nations Victims of Terrorism Support Portal, 2020). The museum team assembled to develop the vision and working guidelines of the museum (still in planning) shared this conviction and sought the experimental as the means by which to think through its museological realisation. The development of this process is how a group of young curators, educators and designers came to challenge a more classical design for the memorial museum premised upon chronology and analogical museography as both an exercise in innovation and integrated planning.

The museum team's methodological approach, which we may qualify as an experimentation in curation and design-thinking enabled museum staff to place an emphasis on the process of development, and notably the concept of 'social construction' it espoused - rather than the ultimate product itself - as the guiding principle of their preliminary work and reflections. As discussed below, social construction entailed building relationships with communities in order to permit dialogic encounters during the conception phases of the museum. When coupled with the team's insistence on reflexivity on its own approach, this method also led to new forms of understanding and interpretation as the outcome of a professional practice that sought to provide Colombians with a visiting experience aimed at opening onto a different kind of understanding of the country's armed conflict: one that would reveal the structural dimensions of the conflict, while encouraging deeper personal introspection and interpretive responsibility in terms of the conflict.

One might also characterise the work as a form of participatory action research (even if not initially articulated as such) or as research-creation, insofar as the lead curator and co-author of this chapter, Cristina Lleras and the museology team, specifically sought the exhibition medium as a collaborative ground of exploration 
for exhibit development and, in wider terms, as a resource for those communities of practice who would further imprint its potential with their own forms of engagement. Guided by the traumatic experience of Colombia's immediate past social history, the exhibition was intended as a venue to collectively seek social change by enhancing opportunities for human agency, multidisciplinarity and a collaborative working framework amidst and across the contributions of community members both throughout conceptualisation and, once inaugurated, in response to the exhibition itself.

In our analysis of this exhibition experiment as a single case study, our focus was on the modalities of curatorial and design-thinking, and not a systematic evaluation of visitor impact. We sought to analyse this process within the larger purview of the emerging phenomenon of human rights museums and teamed up while the pilot exhibition project was underway. Our discussions continued throughout and after the closure of the Voces exhibition, as we further reflected on the theoretical implications of the design process as a means for facilitating meaningful social change. As lead curator of the Museum of Memory, Lleras coordinated the experimental Voces exhibition and oversaw the museology team at the Museum of Memory of Colombia between 2016 and 2018, and she was thus directly implicated in the very processes we discuss in this chapter. Lleras's work as a curator and scholar-practitioner focusses on institutional practices and representations of the past. Carter is an academic who has theorised the emerging phenomenon of human rights museums in different geo-political contexts. If the personal experience of the exhibition-making process and this exhibition's ultimate materialisation constituted the primary data in our investigation, further materials useful to our analysis included exchanges with Lleras's colleagues and on-site visitor evaluations conducted at Voces in Bogotá. Our analysis is thus grounded in a critical, summative reflection of the exhibition-making process and the key design concepts upon which this process was premised - narrative, metaphor and selfreflexivity - as the means for thinking through the potential of a process-as-praxis approach to curation and exhibition design.

With this dual methodological backdrop in mind (the experimental methodology of the museum team and the method of analysis deployed by Lleras and Carter), we recognise the importance of understanding the Museum of Memory as an environment constituted by the interplay of internal (staff) and external (communities) relationships from its very inception as the basis of the potential to rethink the nature of museological praxis and, ultimately, the experiences and agency of the communities museums intend to serve.

\section{The rise of memorial and human rights museums: theory and concepts}

The desire to address and redress trauma and war in productive and conciliatory ways has led many museum professionals to consider how objects and texts, spaces and screens - as the grammar of exhibition design - might best communicate the 
suffering fuelled by humanity's deep conflicts, the hope engendered by its resilience and the ways in which members of society might transform their own stereotypes about armed conflict in order to lead to broader societal transformation. Two types of museums have evolved in this respect: memorial museums beginning in the post-World War II era, and, since the late twentieth, and early twenty-first, centuries, human rights museums. In the former, exhibition design has historically assumed a canonical form, in which chronological narrative, evocative artifacts (including victims' belongings and instruments used in violence) and simulated settings and/or historic architecture provide the grounds for what is intended to enable empathetic encounters with the past. Holocaust museums all over the world have adopted variations of this conventional approach in their ongoing work to commemorate the Shoah's victims of past atrocities, and to fight intolerance, racism and injustices in the present. Some have evolved to include thematic structures in addition to strictly chronological ones in order to display curatorial content amidst evocative or emotive environments. Key examples of this kind include the U.S. Holocaust Memorial Museum in Washington, D.C., with its inclusion of temporary exhibitions about contemporary genocide; Israel's Yad Vashem in Jerusalem highlighting different 'chapters' rather than a linear trajectory in Holocaust history and a greater focus on relaying personal stories of individuals murdered in the Shoah; and, finally, the Sydney Jewish Museum in Australia, which now includes a Holocaust and Human Rights Exhibition that considers human rights issues in the contemporary. A growing literature exists on the subject of memorial museums (Williams, 2007).

Of the second type of museum, the human rights museum, there have been several different approaches within the genre's brief history, including hybrid variations combining both memorialising functions and the discourses and strategies of a larger human rights framework, such as in Chile's Museo de la Memoria y los Derechos Humanos (inaugurated in 2010) and Taiwan's National Human Rights Museum (inaugurated in 2018), both in response to post-dictatorship regimes. Born of transitional justice contexts, ${ }^{2}$ these specific examples seek to commemorate the victims of past atrocities while locating these atrocities within the terms of the fundamental rights that their perpetrators violated. Much like recent developments in memorial museums, the collections and exhibitions of such museums contain historical artefacts combined with a narrative that provides the context of human rights violations and stories of resistance. Yet, while there is an increasing demand to create cultural institutions such as museums to respond to transitional justice measures and, more specifically, to the aims of symbolic reparation, the human rights museum as a museological genre may rightfully still be considered experimental because, no over-arching paradigm exists so far. Moreover, any museum developed under such conditions must respond to the specific requirements of the geopolitical context that gave rise to it, precluding a standard museological and design approach (Carter \& Orange, 2012).

With these thoughts in mind, the founding staff of Colombia's Museum of Memory sought to rethink the precepts of memorial and human rights museums as 
it developed the working guidelines of the museum between 2015 and 2017. There were many reasons for this: with no founding collection and no obvious material artefacts to put on display, the question as to whether to develop a collection for a museum dedicated to the Colombian armed conflict has elicited ongoing debate and remains unsettled. And even though the museum has been conceived to address the darkest of subject matters, staff agreed that they wanted to nurture a different type of response from visitors than that elicited by memorial museums with their use of analogical, and increasingly immersive, museographies that involve viewers in reconstructions of traumatic pasts.

In keeping with the human rights turn in many museums, museum staff sought to propose a range of different forms of engagement and interaction in order to involve visitors cognitively, emotively and reflexively in terms of their future individual and collective behaviour. The difference is of the order of engagement, from subjective identification (consider the use of identity cards) in the memorial museum to one of individual agency (in recognition of the capacity to elicit individual and collective behavioural change) in the human rights museum. This element of the Museum of Memory's philosophy is key: by illustrating the interlinking and structural dimensions of the conflict (drug trafficking, land dispossession, exploitation of natural resources and of Indigenous, Black and peasant communities) and thereby revealing the devastating extent of Colombia's armed conflict, the goals that the museum's staff set for themselves sought to change the way Colombians both individually and collectively understand the impact of war. The staff specifically aspired for the exhibition to appeal to individual and collective senses of responsibility toward politically intervening for the end of war as a consequence of this insight. But significantly, unlike the calls to action that increasingly characterise the approaches of both memorial and human rights museums, the staff felt that it was important to nurture and emphasise self-reflexivity and personal actions over generalised calls for change. Toward this end, they argued that the Museum of Memory:

strongly believes that a narrative of the past is insufficient if it does not lead its people (as a society) to - at the very least - question the ways in which the war and the violation of human rights have been justified by numerous actors involved and, very often, by people who have not directly participated in conflict.

(Lleras et al., 2019, p. 141. Italics added)

Developing the means to elicit self-reflexivity amidst Voces' visiting publics, be they individuals or groups, was thus a fundamental preoccupation of the planning team which sought societal transformation as one of the museum's overarching goals. How might Colombians develop a more complex understanding of the conflict's multiple and overlapping dimensions in order to find, if not political, at least social reconciliation after 60 years of profoundly divisive and devastating armed conflict? Memorial museums have traditionally incorporated analogical designs to immerse visitors into the experiences and subjectivities of others - 
ostensibly asking these visitors to walk in the shoes of another as a way to gain better understanding of a traumatising past. Yet, the museum staff deliberately turned such a museographical technique upside down by asking questions directly of the visitors themselves, probing their individual thoughts about, and experience of, the armed conflict. Thus, at the entrance threshold of the exhibit-museum, visitors came face-to-face with the compelling interrogation: 'What has war left me with?' Diverse emotions ranging from vengeance to hope were plotted on to a wooden panel and visitors were invited to choose which of these emotions best represented their own personal feelings. This question was strategically placed at the beginning of the trajectory in order to highlight the fact that the museographical narrative recounted something that had happened to all Colombians and not, or not only, to 'others.' The exhibition's exit threshold presented a further invitation for visitors to reflect on their role in contributing to positive societal transformation, inspired by what they had witnessed in the exhibit-museum.

Wilfully placing its own vulnerabilities on exhibit, the planning team also unveiled the challenges it too had faced throughout the development process, foregrounding these challenges with the most fundamental question of all: 'Why is it difficult to narrate armed conflict?' Together with a design that stressed the process of consultations throughout the museum's conceptual development, the team chose to emphasise that the story and history of armed conflict - its impact and the ways communities and individuals have responded to it - is an ongoing process, leading the museum staff to stress that it 'could be narrated in many ways' (exhibition text). The manner in which the museum's planning team conceived of the design programme in a flexible and open-ended way was a direct response to this condition, and it provided them with the space of experimentation that a chronological structure would have made difficult, if not incomprehensible.

\section{Developing process for praxis in a new national museum: social construction}

There was no template to guide the thinking about how to design a national museum dedicated to addressing the complexities of the Colombian armed conflict. When the design contest for the building of the Museum of Memory of Colombia was won by a group of Colombian and Spanish architects (Pacheco Estudio de Arquitectura and Estudio Entresitio) in 2015, there was as yet little information on exhibition content for the architects to work with, and only an incipient idea of what the museum's staff intended the visitor experience to be. Yet, while it is not unusual in projects of this magnitude to be conceived along parallel timelines in terms of form and content, architecture and museography, here the specific method devised by the planning team to develop the museum's narrative and conceptual guidelines was a novel departure from conventional practice and was born out of a method coined 'social construction' (Centro Nacional de Memoria Histórica, 2017, p. 49). 
The process of social construction was premised upon connecting with Colombian communities through a series of workshops, community gatherings and projects as well as public events and regional initiatives that were all designed to bring members of the public into contact with the museum's planning team. In addition to providing valuable opportunities to build trust and working relationships between different communities and a national museum, these diverse encounters provided civil society organisations and victims with the important opportunity to collectively imagine what the museum should be like. Over a period of almost four years, members of the museum's staff travelled to the communities of different territories and regions, participated in diverse memorial exercises and thereby gained a range of insights into, and first-hand knowledge of, the complexity characterising the armed conflict and the multiple forms of impact this conflict has inflicted on the Colombian nation and its people over time. The first expression of the museum's identity was thus shaped by social construction and its various outcomes.

As the museum staff worked to synthesise the material collected throughout this process, their goal was to translate the public's - and especially victims' expectations into a vision of what the museum space itself might become, and to share this vision with Colombians. Thus, in an unusual and bold move, the museum team launched a pilot project in 2016 that would bring to the public the working ideas and proposed narrative of the museum before the institution's scheduled opening on its permanent site in Bogotá. The result was a temporary exhibition, Voces para transformar a Colombia (Voices for the Transformation of Colombia), inaugurated in a pavilion at Bogotá's annual book fair in 2018.

Although Voces has all of the elements of an exhibition, in recognition of its distinct role in the identity-making process of a new national museum, we will refer to it here as an 'exhibit-museum': it literally became a means to put (the ideas about) a new museum on display. This novel approach had several different intentions: presented within the context of a major annual cultural event in Colombia's capital, Voces was conceived in order to evaluate the way in which the museum sought to tell the story of the Colombian armed conflict, visitors' interactions and experiences with the different components of this story and what they took away from their visit. In order to do so, in addition to designing the exhibition itself, the team developed a visitor study which comprised two separate methodologies: the first was a quantitative survey which included demographic information and questions about the emotional impact of the exhibition on visitors. The second was an ethnographic study that included thick descriptions about visitors' behaviour and engagement with the exhibition content, researchers' observations and description of visitors' reactions in guided visits and events, as well as focus group interviews conducted after the event. In these ways, Voces functioned as a means to formulate research areas which the institution might further develop. Finally, it provided a way for the museum team to experience the more prosaic dimensions of a functioning museum, that is, the successes and failures of producing a large-scale project together. 
Given its manifold ambitions, it is not surprising that in the making of Voces, the very process of its development was as important as opening the exhibit-museum to the public. Ultimately, this process encompassed the diverse forms of research conducted by staff since the institution's founding, in terms of fieldwork, workshops and interviews, as well as the study visits made by planning team members to other memorial and human rights museums created in the post-conflict or transitional justice contexts of Chile, Argentina, Germany and Perú, and on the soil where memorial museums and human rights museums commemorate violations considered 'far' from such contexts, such as in Canada and the United States. The challenge for the museum team was to translate the wealth of this material and their own reflexive learning into a unique design within the Colombian context. To diversify their approach, the museum staff also took inspiration from the working methods of a wide range of disciplines such as anthropology, architecture and the visual arts, seeking to integrate interdisciplinary and creative processes into the museum's way of doing.

For these reasons, a curatorial storyline was not handed over to the educational and design teams to then work with for future programming and exhibition design as is often the case in traditional museological planning and practice. Narrative, content, form and programming were developed synchronously by staff working in close cooperation and communication with one another towards the common goal of developing a 'different' kind of museum and museum experience.

\section{Innovating a narrative strategy: experimenting with metaphors in Voces}

A major challenge for the museum staff was to overcome the traditional museological model of a linear, progressive narration of events that would support a chronological account of the past. One of the reasons for this decision was pragmatic: Colombians cannot agree on a date marking the beginning of the armed conflict because there have been different cycles of violence in Colombia's modern history. For the country's Indigenous and Black communities, for instance, the armed conflict is but another phase in the much longer history of violence perpetuated against these communities. Given that under the terms of Law 1448, the processes of symbolic reparation are not limited to recent victims of violence, the issue of assigning a time limit - of deciding when to begin the narration of events

and where to end it - became problematic. Another challenge the museum staff faced was avoiding the trap of reproducing a moralising account of 'good and evil.' Although the Law defines who is considered a victim, it does so in an overly simplified and binary way. The Colombian armed conflict is especially complex in terms of who has been victimised and who is considered a perpetrator or responsible party. Paradoxically, these problematic terms have many times generated overlapping categories which are not recognised as yet by judiciary instruments. In one example that brings important nuance to these terms, the Colombian Constitutional Court ruled that a woman who had been recruited by the guerrilla as a minor, and 


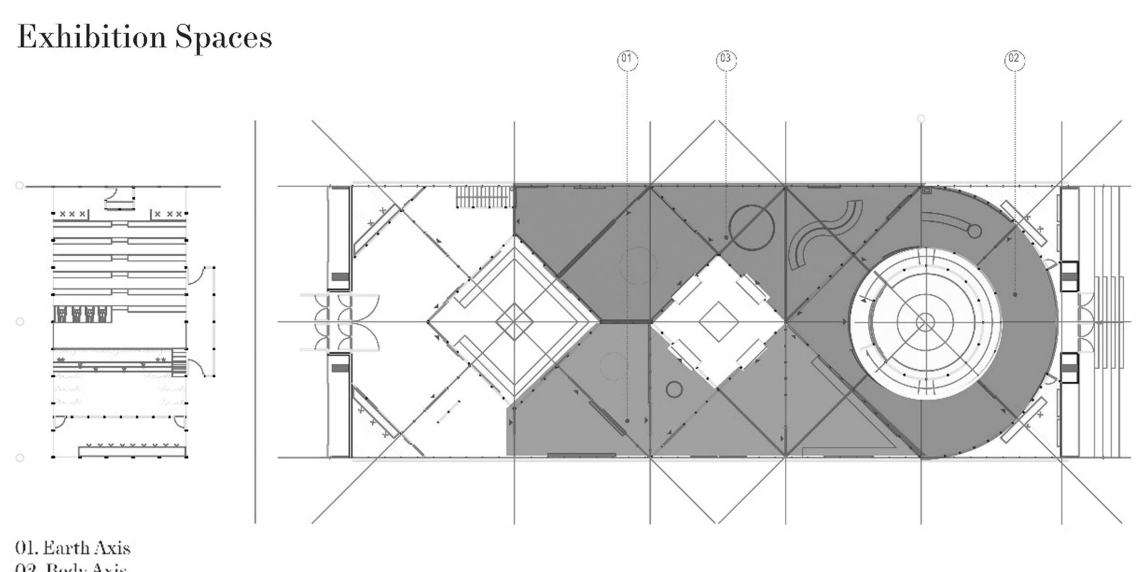

FIGURE 3.1 First-floor plan of the Voces exhibition in Bogotá. The exhibition was divided into three axes: land, body and water. The circular space represents the memorial, a 'house' occupied the centre square and the forum was located to the far left. Photo: Laura Cuervo.

who became a combatant as an adult, was declared a victim of forced recruitment, displacement and sexual violence (Corte Constitucional, 2019).

The team set out to find an avenue to explicitly incorporate not only themes, but specific messages that would provide a deeper analysis of the structure and enabling mechanisms of the conflict (see details in Centro Nacional de Memoria Histórica, 2017). The team ultimately determined three axes for the principal exhibition narrative based on the foundational and metaphorical concepts of body, water and land (Figure 3.1).

These axes emerged from team members' synthesis of research, the information they had collectively gathered and from conversations with senior researchers at the National Center for Historical Memory. The team articulated the polyvalence of the themes in the following way:

- The body is a means to feel, experience and learn and can give a direct account of the damages of armed conflict. The body enunciates directly by silencing and indirectly by the scars it reveals on itself. It is understood as a social and cultural construction, a complex composition of materiality, spirituality, identity and thought which has an individual dimension and a social linkage. For Voices, this axis communicated stigmatisation, intolerance and the elimination of social, cultural and ethnic differences and political dissent that have characterised the armed conflict.

- Water connects and takes the shape of the vessel that contains it. Different bodies of water are the habitats and sites of cultures and communities around the country. Water sustains life and is present in quotidian activities as well as rituals. But in Colombia, these places of life have also been turned into sites of 
death, thereby producing a fundamental tension between water as life-giver and life-taker. The message this axis conveyed was that the costs of armed conflict are too high, and damages are immeasurable. Nothing justifies the violation of human rights.

- Land is materiality, context and landscape. It has an identity linked to how people are rooted. It can be understood as territory in a political sense, and as frontier, control and defense, underscoring how its geopolitical dimension is crucial for all actors. It is also place, a means to understand the people's experiences in armed conflict, such as at sites of memory. Land has been fought over and local communities have been displaced and dispossessed of their land. The message to be conveyed was that armed conflict is intentional and responds to economic, military, political and institutional dynamics and interests.

By intertwining these metaphors, the team understood the museum visit as a unique social encounter for Colombians - with all of their diverse perspectives and experiences of territory and the armed conflict - in which to come together in a single space-time dimension, and consequently set out to narrate the armed conflict in this manner. Rather than a deliberate chronological unfolding with its event-specific structure that is premised upon a didactic appropriation of facts and dates, the planning team foresaw three metaphorical axes that would function as means of bringing people together in new and untested ways for a different kind of understanding: one that would encourage a deep sense of personal responsibility with respect to the exhibition's broader messages.

Thus, the thematic axes became multi-pronged conduits within the museological context, simultaneously serving as literal entries into the museum, as ways to narrate the past, as concepts leading to an expanded understanding of the armed conflict and as the premise of subjects that collectively tell a story. In their broad narrative potential, the axes were non-exclusive and complemented each other. Hence, the exhibit-museum was thought of as an integral narrative and as the sum of its parts, and, in the manner the axes referred to materiality, to the symbolic and the transcendental, but also to the senses, to cosmologies and to different ways of seeing the world, they permitted great curatorial and design latitude.

In order to develop the content for the three axes of the exhibit-museum, team members engaged with different constituents in both informal and group workshop settings. These constituents ranged from internal staff at the National Center for Historical Memory to external stakeholders such as groups of victims and nonvictims already involved in memory processes with the Center, including Indigenous and Black communities, artists and peasant associations. The team posed three fundamental questions: What does the armed conflict do to the body, the land and the water? What do the body, land and water do in armed conflict? And, how do the body, land and water narrate armed conflict? This methodology enabled the team to construct an expansive inventory of documents, initiatives, objects, images, videos, practices, sites, people and archives that would later be 
organised into a script for each axis. Yet the findings of this exercise were still far from 'becoming' an exhibition.

\section{Metaphorical inscriptions, spatial articulations: experimenting with curatorial and design thinking}

The various layers of association each of Voces' three axes evoked enabled a transversal approach to the narration of Colombia's armed conflict. Furthering its ambition to develop an experimental method that could produce a unique curatorial design methodology, the museum team which had initially consisted of anthropologists, curators and educators, expanded to include architects and scenographers who had experience with the design of ephemeral pavilions and theatre sets. The objective of this stage was to determine how to spatialise the axes into museographical renderings and to design visitor experiences that would fully exploit the rich metaphoric, artistic and associative potential of the axes. With no founding collection, there was no list of documents or objects that 'needed' to be included in the exhibition. Rather, narrative dictated content, implying that exhibits could be found, created or produced to fit narrative needs. More broadly, the team imagined the visitor's journey throughout the museum as the sum of a total experience - informed by the exhibition, programming and multimedia events. Each had to be thoughtfully considered and choreographed within a strong narrative construct.

In the design of the exhibit-museum, both individual and collective experiences were considered through the lens of the polyvalence of traditional museum spaces. Visitors were provided with simultaneous programming throughout their visit, woven into and outside of the exhibition as part of the broader exhibitmuseum concept and the holistic experience it sought to offer. In other words, spatial planning was not limited to conventional or individual use: performances took place beyond the auditorium, commemorative practices expanded outside of the memorial setting. Spaces for collective gathering ranged from the forum intended to host conversations about literature, historical memory research, exhibition themes between victims, academics, artists and other members of the general public, to memorial and performance venues, a documentation centre, a radio station with live broadcasting and an educational space, as well as a metaphoric, two-storied house. These spaces were intended to enhance the social experience of the museum-exhibit by multiplying the opportunities to engage in dialogue. While exhibition areas and a physical space for the virtual dimensions of the museum (virtual-reality terminals where users could 'visit' other sites of memory in different parts of the country) were designed for individual visitors, educators and victims ultimately also used these spaces as opportunities to talk to visiting groups and individuals, blurring the distinction between programmed and spontaneous, individual and collective uses of space.

The pavilion of the museum-exhibit was designed, built and operated as a twoweek and ten-day event, respectively, at each of two locations chosen to house it, 
first in Bogotá and subsequently in Colombia's second-largest city, Medellín. Its overall form deliberately reflected this temporal impermanence through a physical appearance that shared greater affinity with the temporality of stage sets than the polished design of most permanent exhibitions: the use of materials, props and lighting and the importance of creating a range of atmospheres appropriate to the different zones of each axis were of paramount importance. These concerns, typical in theatre or performance venues, illuminate yet another experimental approach at play: incorporating the design strategies of other art forms so as to enhance the visitor's spatial rapport with each of the body, water and land axes, and thereby facilitating their understanding of the armed conflict's broad reach. This rapport was further reinforced through first-person narration of body, water and land in each of the axes' introductory texts. Accompanying visitors throughout Voces in this way, this form of anthropomorphism lent immediacy to the narration and served to overcome the distance of objectivity between visitor and the medium of the exhibition. Embodied in voice and articulated in space, each characterisation sought the individual visitor's engagement through the connection established between the cognitive realm and bodily senses. After experimenting with different forms of content organisation and display, it became evident that messages would be lost if the body, water and land axes were combined or mixed. Thus, each axis was given its own area, defined by colour and materiality: fibre for body, clay for land and light-infused projections evoking reflections for water. In this way, the choice of material was both a physical structuring device and a primary design element.

Designing for specific content also required particular techniques. Each axis was divided into case studies in separate rooms that responded to a wide range of criteria in order to ensure that a diversity of examples was represented. Case studies ranged from the dispossession of land of Indigenous communities in Colombia's North and Northeast to the Atrato River as the subject of rights, and they were comprised of a maximum of three exhibits. For example, one case study on urban land dispossession in Medellín consisted of an installation of posters with fragments of testimonies, a multi-projection video installation and life-size photographic portraits and texts with life stories (Figure 3.2).

Each exhibit was chosen or created for the museum according to a medium that would best convey the case study: interactive maps made by Indigenous communities, short documentary videos, graphic narratives, three-dimensional infographic materials, murals, illustrated timelines, photographs, reproductions of personal objects and life histories, audio components, large-scale illustrations, a coca plant. Except for a pair of rings, nothing was installed behind glass. Everything could be touched, and no distinction was made between pieces visitors could or could not interact with.

Objects evoking personal histories were made with the victims whose stories they accompanied. Most of these were copies of original possessions, not infrequently a reminder of one of the few precious things families kept from their lost loved ones. 'Authenticity' in this context was not conferred by the aura of an 


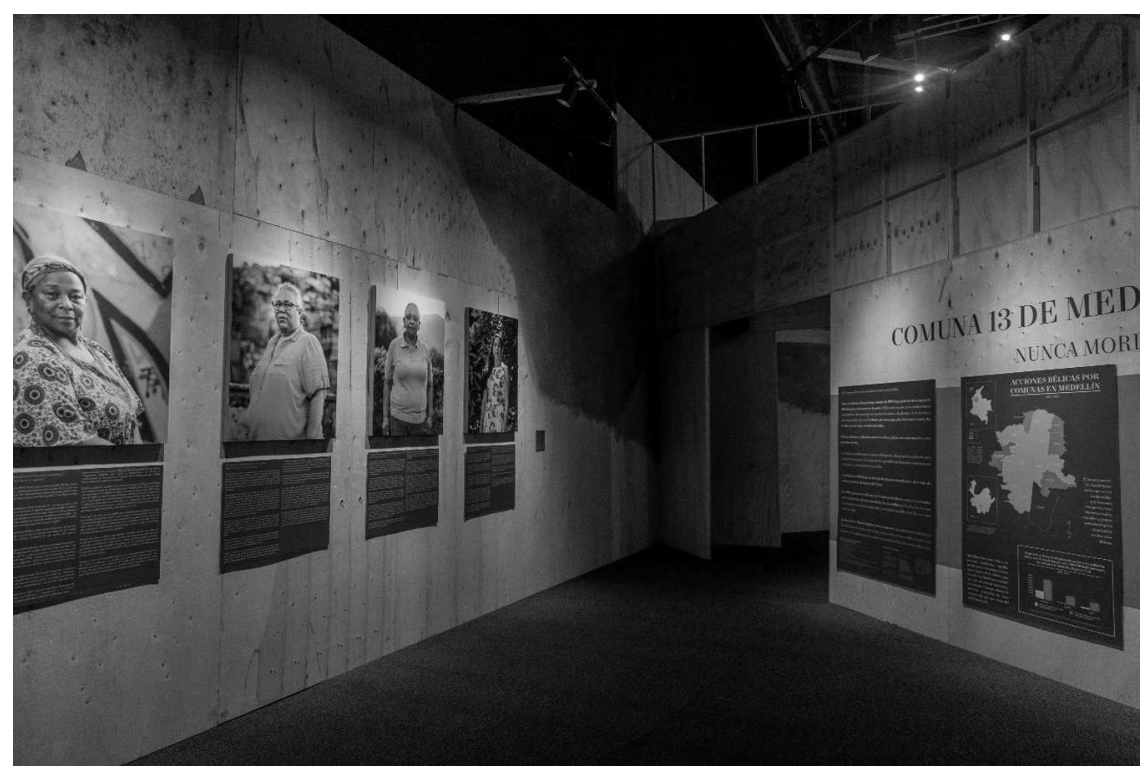

FIGURE 3.2 Life-sized portraits and life histories of female human right leaders in Medellín comprised exhibits in the case study dedicated to Comuna 13, a territory historically marked by displacement and other forms of violence within the city. Photo: María Camila Suárez.

object, as many of these were purpose-made and fabricated for the exhibition. Especially in the body axis, focus was rather on the nature of the experience the object installation and viewing evoked. For instance, one exhibit included a copy of the t-shirt a young Johann Stiven Martínez wore with the photograph of his kidnapped father when Martínez marched over 100 kilometres to demand his father's release. Johann Stiven became an icon and a symbol of the impact of the guerrilla's dehumanising practices because of the many times he appeared in the media. His father, a military man, died after more than 13 years of captivity by the FARC (Fuerzas Armadas Revolucionarias de Colombia). Using victims' belongings and personal objects in this way, whether originals or replicas, was only one of several strategies used by the planning team which deliberately expanded the focus on personal narratives to also include, for example, graphic novels as a means of diversifying ways of representing the past.

\section{Conclusion: the Museum of Memory as a process-as-praxis}

Several testimonies collected throughout the museum's social construction phase referred to the potential of Colombia's new national Museum of Memory to be 'open,' a place for quotidian activities and daily life, a space for life with trees and not cement, with water that cleanses and gives way to rebirth and as 'festive.' Despite all the horror of the conflict, a place alive with people and sounds (Centro 
Nacional de Memoria Histórica, 2017). Curators noted that Colombians seemed to associate the museum less with an idea of the sacred - although they did want it to serve the recognition of victims - and more as a space to inhabit (Centro de Investigación, 2015). Collectively, they imagined the museum as a place to contain different forms of memory, and for making memory as well. Moreover, the idea of the museum as a welcoming house emerged.

Wishing to honour these ideas, the planning team poignantly translated this view of the museum as a space for daily life into one aspect of the pavilion in the form of a two-story house that they symbolically located at the intersection of Voces' three axes. Its presence interjected evocations of exile, abandonment and communities forced to flee within the exhibition's foundational themes of body, water and land, just as it incarnated the symbol of the homes Colombians have built with their own hands and the communities they have nurtured into a cohesive social fabric. Its presence poignantly recalled how the house has been witness to violence, how it has been lost to the millions that have been displaced and dispossessed and - in a final statement epitomising the atrocities committed to the body, water and land in armed conflict - what has been fought for and what, for so many, has been irrevocably lost.

Perhaps this is where process-as-praxis, as one of the planning team's guiding tenets, fully materialised: in the manner the house, bearing the weight of these many associations, was nevertheless thought of as a place for visitors to build things together in an evolving and ongoing way. The result: a part of a larger whole, a narrative that is simultaneously in and about process, promising an always openended and by virtue of this, (productively) incomplete experience for visitors. This is how the planning team experimented with the museum's ontology, not with the intention of imposing a model, but rather to propose a process and praxis. This approach not only necessitated new working relationships amongst the museum staff and communities, but also a greater degree of polyvalence in the manner spaces could be used for Voces' multiple functions. Voces fundamentally experimented with innovative curatorial and design strategies, the museum concept and the interconnection of Colombians and the museum planning team. The many levels of engagement afforded by this spatial flexibility and the holistic thinking that grounded the project were the outcome of this museological experiment.

While much more could be said about the house and about the pavilion, the Voces project defies a conclusion. As such, it is indicative of experimental museology. After all, it is an experiment in something yet to come, where larger political implications loom large. The process coined as 'social construction' is not only the foundation of the museum's first design expression as it materialised in Voces, it should also be incorporated into future developments as an ongoing practice. A change of government, shift in governance or new state priorities can, and may still, bring profound disruption to this highly innovative national museum-in-the-making. In its bid to reshape the terms of an institution that seeks to become both a memorial and a human rights museum, the planning team that put into motion the museum's social construction and engaged in a consultative 
process with Colombians did so with the intention of experimenting the means to transcend traditional approaches to museographical representations of trauma toward something more holistic, and perhaps ultimately, more transformative in its aims and outcomes.

\section{Notes}

1 According to the United Nations Victims of Terrorism Support Portal, 'The Center accomplishes its purpose by reconstructing, through the testimony of victims, the serious human rights violations that occurred in the framework of the conflict, searching for truth, justice, reparation and the construction of a sustainable and lasting peace' (United Nations Victims of Terrorism Support Portal, 2020, n.p.). https://www.un.org/ victimsofterrorism/en/node/568.

2 The Global Initiative for Justice, Truth + Reconciliation defines transitional justice as 'the set of measures and processes that aim to end impunity, redress victims of grave human rights violations, and re-establish the rule of law' in a given country (Global Initiative for Justice, Truth and Reconciliation, 2017, p. 8).

\section{Bibliography}

Carter, J., \& Orange, J. (2012). Contentious terrain: Developing a human rights museology. Museum Management and Curatorship, 27(2), 111-127.

Centro de Investigación y Educación Popular, CINEP/Programa por la Paz. (2015). Resultado de la sistematización y análisis sobre Perspectivas de las víctimas del conflicto armado frente a la creación del Museo Nacional de la Memoria: estrategia de inclusión y participación ciudadana para la creación del Museo Nacional de la Memoria [Results of the systematization and analysis of perspectives of the victims of the armed conflict leading to the creation of the National Museum of Memory: Strategy of inclusion and citizen participation for the creation of the National Museum of Memory]. Internal report. Unpublished. Centro de Investigación y Educación Popular, CINEP/Programa por la Paz.

Centro Nacional de Memoria Histórica. (2017). Museo Nacional de la Memoria: Un lugar para el encuentro. Lineamientos conceptuales y guion museológico [National Museum of Memory: A place for encounter. Conceptual guidelines and museological narrative].Centro Nacional de Memoria Histórica. http://www.centrodememoriahistorica.gov.co/informes-2017/ museo-nacional-de-la-memoria-un-lugar-para-el-encuentro-lineamientos-conceptuales-yguion-museologico

Centro Nacional de Memoria Histórica. (2018). Los caminos de la memoria histórica [The paths of historical memory]. Centro Nacional de Memoria Histórica. http://www. centrodememoriahistorica.gov.co/micrositios/un-viaje-por-la-memoria-historica/pdf/ los-caminos-de-la-memoria-historica.pdf

Corte Constitucional ordena reconocer como víctima a exguerrillera forzada a abortar [Constitutional Court orders the recognition of victim of a former guerrilla who was forced to abort]. (2019, 11 December). El Espectador. https://www.elespectador.com/ noticias/judicial/corte-constitucional-ordena-reconocer-como-victima-exguerrilleraforzada-abortar-articulo-895419

Global Initiative for Justice, Truth and Reconciliation. (2017). Building a learning community: Lessons for a holistic and sustainable approach to transitional justice. International Coalition of Sites of Conscience. https://www.sitesofconscience.org/wp-content/uploads/2017/ 12/TJ-Toolkit-6x9-online.pdf 


\section{Jennifer Carter and Cristina Lleras}

International Center of Transitional Justice. (2020). Transitional justice mechanisms in Colombia. https://www.ictj.org/sites/default/files/subsites/colombia-timeline/index_eng.html

Lleras, C., Forero, M.A., Diaz, L., \& Carter, J. (2019). Memory exercises: Activism, symbolic reparation, and non-repetition in Colombia's National Museum of Memory. In R. Janes \& R. Sandell (Eds.), Museum activism (pp. 139-151). Routledge.

Stengers, I. (2015). In catastrophic times: Resisting the coming barbarism. Open Humanities Press. Original work published in French in 2009.

Thiemeyer, T. (2019). Multi-voiced and personal: Second World War remembrance in German museums. In J. Echternkamp \& S. Jaeger (Eds.), Views of violence: Representing the Second World War in German and European museums and memorials (pp. 27-51). Berghahn.

Unidad de Víctimas. (n.d.). https://www.unidadvictimas.gov.co/en

United Nations Victims of Terrorism Support Portal. (2020). The National Center for Historical Memory's [sic]. https://www.un.org/victimsofterrorism/en/node/568

Williams, P. (2007). Memorial museums: The global rush to commemorate atrocities. Berg. 